\title{
SEMIOTIKA ATRIBUT SEBAGAI PESAN KOMUNIKASI: STUDI KASUS ATRIBUT IBU ANGGOTA DPR RI
}

\author{
Dominikus Tulasi \\ Marketing Communication Department, Faculty of Economic and Communication, BINUS University \\ Jln. K.H. Syahdan No. 9, Palmerah, Jakarta Barat 11480 \\ dtulasi@binus.edu
}

\begin{abstract}
Research aims to know denotative and connotative meaning of the attributes used by female members of House of Representatives as an integrated signifier and signified in their appeance. In terms of the research context "performance" was "sign" itself, by seeking the new structure existing in the attribute of their appearance. Attribute denotative meaning is the overall objects seemed. Connotative meaning is the meaning existing fits to the context of local culture, within it loads particular human being expression individually. The method used in the study is inductive-posteriori-explorative-qualitative, with a case study using semiotic analysis of communication led to internalization of the researcher towards the phenomenon of attributes used by the female members of the House of Representatives. The choice and use of attributes in each appearance can be used to give impressions used an anchor by the researcher to provide further interpretation of the attributes worn. This study took the paradigm theory of Ferdinand de Saussure and Charles Sanders Peirce to see through its problems in the field. The result is Saussure's view is able to reconstruct all objects visible to the researcher. Similarly, Peirce's view has three major characteristics that are capable of being a mirror to see the reality in the field. The results showed an attempt to reconstruct the understanding of semiotics and attributes as a form of nonverbal communication message. The study concludes the denotative meaning of attributes can provide communication and connotative message over the attributes used by female members of the Parliament.
\end{abstract}

Keywords: denotative-connotative, binary opposition, signifier-signified, structure, non-verbal communication

\begin{abstract}
ABSTRAK
Penelitian bertujuan untuk mengetahui makna denotatif dan menggali makna konotatif atribut yang digunakan ibu-ibu anggota Dewan Perwakilan Rakyat RI sebagai penanda dan petanda yang menyatu dalam penampilan mereka. Dalam konteks penelitian "Penampilan" adalah "Tanda” itu sendiri, dengan mencari struktur baru yang terdapat pada atribut penampilan mereka. Makna denotatif atribut adalah semua objek yang nampak. Makna konotatif adalah makna yang dihadirkan peneliti sesuai konteks dan budaya lokal, yang di dalamnya bermuatan ekspresi khas individu manusia. Metode yang digunakan dalam penelitian adalah induktifaposteriori-eksploratif-kualitatif dengan studi kasus menggunakan analisis semiotika komunikasi, yang bermuara pada internalisasi peneliti terhadap fenomena atribut yang digunakan ibu-ibu anggota DPR. Pilihan dan penggunaan atribut dalam setiap penampilan dapat memberi kesan yang dijadikan jangkar bagi peneliti untuk memberi interpretasi lebih jauh tentang atribut-atribut yang dikenakan. Penelitian ini mengambil paradigma teori Ferdinand de Saussure dan Charles Sanders Peirce sebagai spektrum untuk meneropong masalah di lapangan. Hasilnya adalah pandangan Saussure mampu merekonstruksi semua objek yang nampak bagi peneliti. Demikian juga pandangan Peirce memiliki tiga ciri besar yang mampu menjadi cermin atau kacamata untuk melihat kenyataan di lapangan. Hasil penelitian menunjukkan upaya merekonstruksi pemahaman peneliti tentang semiotika atribut sebagai bentuk pesan dan komunikasi nonverbal. Penelitian menyimpulkan pemaknaan atribut secara denotatif dapat memberikan pesan komunikasi dan konotasi atas atribut yang digunakan oleh ibu-ibu anggota DPR.
\end{abstract}

Kata kunci: denotatif-konotatif, oposisi biner, penanda-petanda, struktur, komunikasi non-verbal 


\section{PENDAHULUAN}

Pertama-tama ditengarai bahwa Semiotika Komunikasi di jurusan ilmu komunikasi strata satu beberapa perguruan tinggi di Indonesia, perkembangannya tidaklah menggembirakan. Hal ini dapat dipahami sebab semiotika merupakan bagian yang lebih dekat dengan filsafat. Mayoritas dosen ilmu komunikasi tidak menyukai ilmu yang bersifat abstrak atau imajiner. Bagi mereka ilmu yang abstrak tidak praktis untuk kehidupan. Itu sebabnya para mahasiswa jurusan ilmu komunikasi dan juga dosendosennya kurang berminat terhadap semiotika. Diskursus dan pertanyaan yang terkait semiotika umumnya mengharapkan jawaban yang lebih dalam karena pengertian dan definisi tentang semiotika sangat luas. Keluasan definisi semiotika inilah yang memberi akar terdalam bagi fundamental bahasa komunikasi semiosis.

Semiotika membutuhkan antusiasme dan gairah yang tinggi untuk mendiskusikan, memahami, dan mendalaminya. Hanya itu cara yang menarik untuk "masuk" ke dalamnya. Jika ilmu-ilmu sosial seperti sosiologi, antropologi, sejarah, dan ilmu sosial lainnya melihat fenomena di seputar permukaan yang mengisi histori dan budaya manusia, semiotika mencari dan menyelam ke dalam tubuhnya fenomena untuk menemukan makna yang "terbaring” di baliknya.

Keengganan sebagian dosen ilmu komunikasi pada pengetahuan semiotika, terkait erat dengan masalah epistemologi, yakni ruang gerak metode bagaimana memproses dan mengolah fenomena membentuk paradigma ilmiah berupa konsep dan proposisi-proposisi bakal teori. Semiotika adalah ilmu tentang 'sesuatu' (something) atau ilmu tentang segala sesuatu. Definisi ini terasa luas dan tak terbatas namun sangat mencakup jika dibandingkan dengan pengertian semiotika sebagai ilmu pertandaan (signification). Oleh karena pengertian "tanda" dalam bahasa Indonesia akan menghantar kognisi manusia untuk menangkap tanda-tanda visual, tanda-tanda yang tertangkap oleh mata, dan itu tidak salah. Akan tetapi, cakupannya tak terbatas hanya pada pengertian itu saja.

Roland Barthes penerus Saussure dan ahli semiotika post-strukturalis melihat signifikasi sebagai sebuah proses total dengan susunan yang telah terstruktur dalam paham strukturalisme. Sementara Eco (2009) mendefinisikan tanda sebagai 'sesuatu yang mewakili sesuatu yang lain'. Barthes berpendapat, signifikasi tidak terbatas pada konteks bahasa, tetapi melainkan lebih dari itu menjangkau semua hal lain di luar bahasa. Ia bahkan menganggap semua aktivitas sosial termasuk cara manusia berpakaian adalah sistem tanda. Dengan kata lain, semua peristiwa yang mengitari hidup manusia sebagai makluk sosial termasuk atribut-atribut yang digunakan manusia adalah tanda itu sendiri. Penelitian ini sedikit mengungkap makna yang bersifat struktur sekaligus merambah pemahaman post-strukturalisme berdasarkan paradigma berpikir Ferdinan de Saussure dan paradigma signifikasi triangulasi Charles Sanders Peirce.

Secara induktif partikular aposteriori ditemukan kenyataan yang bersifat hybrid yang terungkap di luar bangunan logika struktural. Bahasa semiosis komunikasi pada penelitian ini fokusnya merekonstruksi semua hal terkait "atribut" terlihat sebagai tanda dalam konteks binary opposition seperti yang disaksikan pada paham strukturalisme Ferdinand de Saussure. Akan tetapi, kenyataan ditemukan proses konstelasi permainan penanda yang tanpa akhir dalam konteks budaya; yang pada paham strukturalisme, penanda dan petanda dianggap hidup di dalam struktur yang menyatu, seperti selembar kertas, sebagaimana dikatakan Saussure (Piliang, 2010).

Dengan demikian, membaca ruang penanda sebagai pesan informatif bahasa semiosis, sangat tergantung kepada persepsi dan latar belakang yang mengitarinya. Bertolak dari semiotika Saussure dan Peirce, Peneliti mendalami "atribut” ibu-ibu anggota DPR RI di senayan sebagai sebuah "tanda". Secara intuitif umumnya ibu-ibu yang bersinggungan langsung dengan "dunia atribut" dan ingin berpenampilan untuk memantaskan diri sebagai wujud keindahan dalam sistem kultur yang 
berkembang pada dunia feminisme. Mengenai tampil menarik, ibu-ibu lebih membutuhkan dan mendetail jika berbicara tentang atribut. Semua atribut yang dikenakan ibu-ibu umumnya jauh lebih "terlihat" dibanding dengan atribut dari kaum maskulin. Ini bukan persoalan gender, melainkan secara alamiah mereka lebih "menggumuli" bagian penampilan sebagai "atribut". Hal ini bukan suatu persepsi, melainkan praxis kehidupan kaum wanita. Dalam kaitan inilah, peneliti melihat atribut sebagai suatu realitas yang dapat dibaca dengan bahasa semiosis komunikasi berdasarkan jangkarnya.

Dengan menunjuk pandangan Saussure dan Peirce, penelitian berupaya melihat fenomena berdasarkan paradigma kedua tokoh semiotika tersebut terhadap sesuatu yang visual untuk menemukan makna denotatif dan konotatif tingkat kedua sesuai nilai-nilai budaya lokal kontekstual yang bersifat emotif. Mengacu pada pandangan di atas, muncul pertanyaan: (1) Apa yang menjadi alasan dasar bagi ibu-ibu anggota DPR RI untuk menggunakan atribut 'tertentu' dalam berpenampilan? (2) Bagaimana ekspresi dan emosi ibu-ibu anggota DPR RI ketika mengenakan atribut 'tertentu', baik dalam suasana formal maupun non-formal? (3) apa makna denotatif dan konotatif dari atribut yang dipakai ibu-ibu anggota dewan perwakilan rakyat Republik Indonesia? Pertanyaan derivatif adalah manakah penanda (signifier) dan petanda (signified) dari atribut yang dikenakan ibu-ibu anggota dewan terhormat sebagai wakil rakyat Indonesia?

\section{Studi Pustaka}

Secara etimologis, istilah semiotika berasal dari kata Yunani semeion "tanda" (sign). Jadi semiotika didefinisikan sebagai ilmu tanda dan studi tentang sistem, aturan-aturan dan konvensikonvensi yang memungkinkan tanda memiliki makna (semiotics can be defined as the science of signs and the study of the systems, rules and conventions that allow these sign to have meaning (Yunus \& Tulasi, 2012). Tanda juga didefinisikan sebagai sesuatu dan atas dasar konvensi sosial yang dibangun sebelumnya dianggap mewakili sesuatu yang lain. Secara terminologis, semiotika didefinisikan sebagai ilmu yang mempelajari sederetan objek-objek, peristiwa-peristiwa, dan seluruh kebudayaan sebagai tanda. Dengan kata lain semiotika adalah sebuah teori komunikasi yang didasarkan pada linguistik Ferdinand de Saussure (Eco, 2009).

Menurut sejarahnya ilmu semiotika bermula dari ilmu linguistik dengan tokoh utamanya Ferdinand de Saussure (1857-1913). Meski Saussure lebih populer sebagai Bapak Linguistik, namun idenya di bidang semiotika dirujuk ilmuwan semiotik sesudahnya. Saussure membayangkan suatu ilmu yang mempelajari tentang tanda-tanda yang digunakan dalam realitas sosial dan budaya manusia. Semiotika didasarkan pada asumsi selama tingkah laku membawa makna dan berfungsi sebagai tanda, ada di baliknya sistem pembedaan dan konvensi yang memungkinkan makna itu ada. Di mana ada tanda, di sana ada sistem (de Saussure, 1988).

Dalam paradigma Saussure, bahasa terdiri dari sejumlah tanda yang terdapat dalam jaringan sistem dan disusun dalam struktur-struktur tertentu. Saussure mencontohkan kata arbor (Latin) yang artinya pohon. Kata ini terdiri dari arbor (pohon) dan konsep tentang arbor (pohon). Singnifiant (arbor) disebut citra akustik yang memiliki relasi dengan konsep pohon (bukan pohon tertentu) yakni singnifie/signified. Tidak ada hubungan langsung dan alamiah antara penanda (signifier) dan petanda (singnified). Hubungan ini disebut relasi arbitrer. Hal yang mensahkan hubungan ini disebut konvensi...." a body of necessary convention adopted by society to enable members of society to use their language faculty" (Saussure, 1986).

Charles Sanders Peirce memperkenalkan tiga jenis tanda yakni, Icon-Index-Simbol. Icon adalah tanda yang mempunyai hubungan keserupaan atau peniruan dari realitas asli sebagai rujukannya. Contoh mengenai icon, foto adalah realitas palsu yang meniru dan merujuk pada realitas asli yakni manusia atau objek sebagai rujukannya. Hubungan antara manusia asli dengan fotonya memang sangat serupa. Namun, harus dikatakan bahwa foto adalah realitas palsu yang menyerupai 
aslinya, tetapi bukan realitas asli. Sebaliknya, realitas asli adalah makluk manusia yang nampak oleh panca indra kita. Sedangkan, index adalah tanda yang mempunyai hubungan sebab-akibat dengan objek rujukannya. Contohnya, hubungan antara asap dan api. Kita bisa katakan bahwa timbulnya asap karena ada apinya. Dan simbol adalah tanda yang mempunyai hubungan arbitrer (arbitrary relation) dengan objeknya, yakni hubungan yang sewenang-wenang atau artifisial. Misalnya hubungan antara kata "ayah" dengan "makluk” yang di-ayah-kan yang tertangkap oleh indra manusia.

Dua tokoh semiotika lain adalah Roland Barthes dan Ernst Cassirer yang mempelajari tanda sebagai suatu tingkatan yang memiliki makna dan karakter dalam aktivitas yang mewujud dalam beragam budaya manusia, seperti bahasa, seni, mitos, ritual keagamaan, sejarah, bahkan ilmu pengetahuan dan teknologi. Studi Barthes lebih fokus pada cara tanda-tanda dialami sesuai konteks budaya masing-masing kelompok manusia. Sebagai contoh Barthes membedakan antara dua tingkatan signifikasi yakni 'denotatif' bermakna literal sebagai level pertama yang disebutnya bentuk, dan konotatif bermakna kontekstual kultural yang diasosiasikan dengan mitos dan memasuki wilayah 'metabahasa' (Barthes, 1990), yang disebutnya konsep.

Jadi makna konotatif 'petanda' dalam konteks Barthes adalah makna yang disesuaikan dalam konteks budaya dan tradisi, yang di masa silam direproduksi ke dalam acara-acara ritual. Acara ritual di masa silam direproduksi sebagai 'tanda' (sign) dan dianggap sebagai sistem ritualitas. Misalnya, pakaian-pakaian tertentu hanya diperuntukkan bagi para rahib dan memiliki makna ritual dan bahkan bermakna religius seperti pakaian pendeta, pakaian raja atau orang-orang suci (Eliade, 1989). Tandatanda bahasa bagi para pendoa juga dikategorikan dalam kelompok tanda sebagai fundasi dalam melaksanakan ibadah. Dalam beberapa acara keagamaan 'tanda-tanda' dianggap sakral dan direproduksi sebagai kekuatan yang bernilai religius, oleh karena kepemilikan tanda memerlukan kekuatan asali (Levy-Strauss, 1964).

\section{METODE}

Pendekatan yang digunakan dalam penelitian ini adalah paradigma induktif-kualitatif dengan pendekatan semiotika komunikasi untuk mendekati masalah dari sisi dan aspek yang tidak hanya bersifat kualitatif-eksploratif-interpretatif. Paradigma penelitian lebih jauh melibatkan pendekatan semiotika struktural Ferdinand de Saussure dan Charles Sanders Peirce sebagai alat dalam menganalisis fakta atribut penampilan sebagai Penanda (Signifier) dan Petanda (Signified) yang ujungnya menghasilkan "Tanda” (Sign) sebagai sebuah kesatuan sistem utuh dan komprehensif. Meskipun demikian tetap membuka kemungkinan mendapatkan wujud tahap turunan yang disebut Barthes sebagai tahap kedua. Pada tahap pertama penelitian melihat masalah secara "denotatif" sebagai bentuk; dan pada tahap kedua penelitian "meraba” fakta secara "konotatif" sebagai konsep. Denotatif dalam pengertian melihat realitas secara tekstual sesuai eksistensinya. Konotatif dalam arti memberi makna dan membuka pemaknaan yang lebih terbuka sesuai konteks budaya lokal yang terbuka bagi pemaknaannya.

\section{HASIL DAN PEMBAHASAN}

Menghadirkan fenomena "atribut" penampilan dari ibu-ibu anggota DPR RI sebagai unit analisis merupakan subjek penelitian ini. Hari-hari yang dipenuhi dengan pakaian batik sebagai manisfestasi kebanggaan ibu-ibu anggota DPR RI tidak selamanya terpenuhi dalam "hasrat” berbusana mereka. Adakalanya masing-masing ibu anggota DPR menampilkan busana sesuai selera masingmasing. dalam keseharian yang dipenuhi acara rapat maupun seminar, umumnya mereka 
menggunakan pakaian batik sebagai ciri khas. Pertanyaannya adalah apakah ibu-ibu anggota DPR ingin menampilkan budaya lokal dan pakaian hasil produksi dalam negeri sendiri? Ataukah mereka ingin menunjukkan kecintaan mereka pada produk budaya sendiri? Semua pertanyaan terjawab tuntas manakala peneliti menggunakan pandangan dan kacamata semiotik struktural sebagai sebuah totalitas dalam tatanan berbusana ataupun berpakaian yang dilengkapi dengan atribut-atribut lain sebagai pelengkapnya dari yang seharusnya dan sepantasnya seorang ibu anggota DPR berbusana.

Mengajukan pertanyaan seputar berbusana, setiap ibu anggota dewan memberikan jawaban yang sangat kompleks dan bervariasi. Peneliti dapat memahami karena latar belakang pendidikan dan cara berpikir yang berbeda antara satu ibu dengan ibu lainnya. Yang menarik perhatian adalah pola berpenampilan ternyata sangat ditentukan oleh latar belakang. Latar belakang yang dimaksudkan utamanya adalah tingkat pendidikan. Konteks proses penelitian ini mengategorikan ibu-ibu anggota dewan perwakilan rakyat ke dalam tiga kelompok agar terlihat wujud dan bentuk formal tampilan seorang anggota dewan perwakilan rakyat. Pertama, adalah kelopok ibu-ibu yang berasal dan berlatar belakang dari desa, yang kesehariannya bergumul dengan hidup dan kehidupan yang sederhana. Pada kelompok ini, umumnya mereka interns, memiliki komitmen yang tinggi, dan nampak berupaya memenuhi harapan setiap yang membutuhkan mereka. Kedua, adalah kelompok yang berlatar belakang keluarga terdidik (educated people). Pada kelompok ini, disiplin diri tinggi dan komitmen pada janji sangat diutamakan. Mereka mencintai semua hal yang berkorelasi dengan nilai ilmiah. Ketiga, kelompok yang berlatar belakang pedagang, seniman, artis, dan pebisnis. Pada kelompok ini, penelitian tidak menjustifikasi kehidupan mereka, tetapi sisi lain yang tak dikehendaki adalah mereka sulit berkomitmen, terdapat kesan meremehkan nila-nilai kehidupan dan cendrung melihat diri sebagai pusatnya.

Dalam kacamata semiotika, ketiga kelompok yang dikategorikan peneliti selama penelitian berlangsung, sudah terlihat dan memerlihatkan jangkarnya masing-masing untuk diberi interpretasi bahwa, latarbelakang dan pengalaman pendidikan dalam arti luas memberi warna dan ketegasan dalam bersikap, bertutur, menyapa, menyambut tamu, keceriaan, dan upaya memenuhi harapan orang lain menjadi sangat tampak. Gambaran ini berkorelasi dengan cara berbusana dan beratribut. Pada kelompok pertama, mereka tampil simpel apa adanya, sederhana, termasuk cara berbusana dan beratribut. Namun, kutamaan nilai-nilai kehidupan menjadi pusat perhatian. Kelompok ini, lebih tegas dalam hampir semua aspek yang terlihat, selain berkomitmen, mereka tegas dan bersikap lebih terbuka. Pada kelompok ketiga, banyak kecenderungan yang menurut interpretasi peneliti, mereka terbiasa dimanjakan oleh lingkungan yang kurang kondusif, dalam memenuhi harapan konstituen. Seandainya peneliti sebagai peneliti menggolongkan diri sebagai konstituen untuk menyalurkan aspirasi peneliti, maka peneliti akan berbelok tidak memilih kelompok ketiga ini. Hal inilah yang mendorong peneliti untuk menarik simpulan sementara terhadap kelompok ketiga, bahwa menjadi anggota dewan perwakilan rakyat sesungguhnya didorong oleh dukungan lingkungan, dan bukan kemauan yang "comes from within" untuk mengabdi pada kepentingan rakyat, melainkan impian untuk terlihat dan mengaktualisasikan dirinya.

Dirunut dalam konteks paham semiotika struktural, dan direlasikan dengan pakaian batik yang dikenakan ibu-ibu anggota dewan dari ketiga kelompok yang disebutkan sesungguhnya adalah manifestasi dan aktualisasi budaya lokal, yang dapat bermakna denotatif dan konotatif sekaligus. Dalam konteks ini berbusana batik sebagai totalitas dalam tatanan berbusana, menampakkan kecintaan ibu-ibu anggota dewan perwakilan rakyat pada budaya lokal yang memiliki makna dan keluhuran nilai. Roland Barthes menyebutnya sebagai "bentuk" (signifier), yang dibaliknya berkonotasi aktualisasi nilai-nilai lokal yang terangkat dan diangkat ke permukaan publiknya (signified). Totalitas makna pakaian batik hanya dapat ditangkap dalam konteks budaya lokal dan budaya yang "menyembunyikan" makna dibaliknya. Akan tetapi makna yang tersembunyi itu tidak dibaca untuk sebuah prestise; melainkan, suatu penampilan yang dimitoskan karena kebanggaan sebagai anggota dewan yang mewakili rakyat. Tahap selanjutnya dipetakan sebagai hasil produksi dalam negeri 
sendiri. Pertanyaan dasarnya adalah, apakah totalitas kebermaknaan berbusana batik memiliki perbedaan mendasar dibandingkan dengan berbusana selain batik atau jenis pakaian lainnya?

\section{Pembahasan Analisis}

Dalam konten analisis penelitian ini, kita berada dalam dua oposisi yang berdialektika, yakni antara ibu-ibu angota dewan perwakilan rakyat sebagai manusia yang berbudaya dan cara berbusanaberatribut sebagai manifestasi tindakan budaya itu sendiri. Berbusana dan beratribut adalah berbudaya yang berdialektika dengan pemakainya yakni ibu-ibu anggota dewan perwakilan rakyat. Dialektika atribut penampilan dalam berbusana, mendapatkan legitimasinya pada aliran post-positivisme yang dikembangkan dari ajaran Plato tentang dunia idea dan humanisme serta rasionalitas manusia untuk merefleksikan budaya sebagai bagian tak terpisahkan dari hasil produksi manusia subjek budayanya. Gagasan Plato memengaruhi Edmun Husserl pelopor aliran fenomenologi yang menekankan bahwa terdapat sintesis antara kesadaran rasio manusia dengan fenomena kehidupan yakni tindakan berbudaya, termasuk tindakan beratribut yang selalu berhubungan secara dialektis.

Dalam pandangan peneliti, dialektika fenomena beratribut anggota dewan perwakilan rakyat adalah sisntesis yang menabrakan dua unsur sekaligus. Unsur pertama adalah akumulasi kepentingan individu yang bersintesis dengan kepentingan kelompok atau partainya. Kepentingan partai adalah manifestasi kepentingan individu, dan kepentingan individu adalah expresi manifestasi kepentingan partai. Kepentingan individu dan partai adalah opsisi keduaan (binary opposition). Dalam kaitan oposisi ke-dua-an, peneliti memandang jabatan dewan perwakilan rakyat sebagai wadah yang istimewa dan agung. Meskipun begitu, keagungan lembaga ini ternyata tidak seluruhnya diisi oleh orang-orang yang agung dan cerdas, melainkan dijabat oleh dua jenis manusia yang beroposisi dalam hampir semua aspek kepentingan untuk menampakkan eksisitensinya sebagai anggota dewan perwakilan rakyat. Pada kelompok kedua dalam analisis penelitian ini, sesungguhnya beroposisi dengan anggota dewan kelompok ketiga. Pada kelompok kedua hasrat untuk berkomitmen sangat tinggi dan kelompok ketiga berhasrat untuk santai dan bebas. Kelompok kedua beratribut dan berbusana dalam rangka memelihara suasana formal; sementara kelompok ketiga berbusana dan beratribut pada situasi dan kondisi yang lebih fashionable dalam kesantaian.

Dalam pandangan fenomenologi sesuatu tampak pasti bermakna menurut subjek, dan tindakan beratribut adalah fenomena yang menampakkan makna denotatif dan makna konotatif yang dapat didistingsikan secara kualitatif namun sulit memisahkannya. Oleh karena, ia hanya membutuhkan pemaknaan kualitatif dan internalisasi subjek manusia pemiliknya. Fenomena semacam ini hanya membutuhkan pengakuan tentang adanya dan bagaimana beradanya, oleh karena kesadaran rasio manusia. Kesadaran sebagai subjek peneliti yang memberi makna tertentu pada fenomena beratribut, adalah substansi dan esensi yang tidak hanya melahirkan ekspresi nilai sopan-santun, akan tetapi kedalaman-nya mencakup nilai estetika dan seni sekaligus. Dengan kata lain, batik sebagai batik dengan pernik-perniknya adalah actus-signifier yang menampakkan apa muatan dan tampilan yang terlihat. Namun, makna dibalik actus signifier adalah animus signified yang perlu diangkat ke-dalaman-nya melalui internalisasi subjek pemiliknya oleh kasadaran terhadap objek tersebut, yakni pakaian batik sebagai atribut penampilan.

Kembali pada semiotika, manusia dihadapkan pada dua dimensi kesadaran. Pertama, kesadaran akan cara beratribut; dan kedua, bagaimana ibu-ibu sebagai subjek budaya beratribut memaknai tindakan beratribut itu, sebagai manifestasi budayanya. Dalam kesadaran berpikir induktif post-positivistik, berbusana sebagai beratribut merupakan tindakan kualitatif, dan yang menjadi substansi dan esensi beratribut adalah keindahan berestetika dalam lingkaran budaya, yang di dalamnya makna konotatif terbaring di baliknya. Dengan pendekatan kualitatif induktif, substansi dan kerangka pikir seluruhnya, bertumpu pada upaya kontemplasi untuk memaknai actus signifier-nya, yakni atribut penampilan dalam berbusana. 
Substansi penelitian kualitatif ini, hakikatnya bersumber dari diri peneliti sendiri. Oleh karena itu, validitas dan reliabilitas bertumpu pada diri sebagai actus yang menyadari, dan bagaimana diri merefleksikan fenomena ber-atribut penampilan. Penelitian kualitatif ini lebih fokus pada substansi dan esensi atribut berbusana dan berpenampilan. Dengan demikian, realm of meaning dari atribut penampilan ibu-ibu anggota dewan, sesungguhnya bersemayam dalam logika dan konstruksi pikir peneliti sendiri. Sebagai peneliti, peneliti paham bahwa, peneliti tidak pernah memulai sesuatu dari titik "nol" untuk meretas dan menetaskan suatu pengetahuan praxis. Peneliti hanya merefleksikan dan merekonstruksi masalah di lapangan.

Akan tetapi, harapannya adalah bahwa peneliti telah mencatat, menyerap dan merunut semua masalah secara metodis serta memproduksinya dengan baik melalui bahasa yang sistematis pula. Peneliti menyadari bahwa, apa yang diekspresikan dalam proposisi-proposisi dan kalimat-kalimat yang merupakan hasil refleksi kesadaran adalah ungkapan pengalaman langsung di lapangan. Oleh karena, dalam menjalankan penelitian ini, peneliti sesungguhnya tidak hanya mengamati dan menjauh. Namun, berupaya mendekat dan berdialok dengan sumbernya yakni ibu-ibu anggota dewan. Peneliti mengenal, dan sumber-sumber terinformasi juga mengenal. Mereka paham akan tugas peneliti, dan penelitipun menyadari intensitas kajian peneliti sebagai yang belajar di lapangan. Pada titik inilah peneliti menyadari sepenuhnya bahwa, peneliti sedang men-dekonstruksi suatu masalah yang rumit dan menantang untuk mengungkapnya dari perspektif semiotika. Bersemiotika berarti bertanya tentang bagaimana sebuah kata dan tanda bermakna. Sebaliknya, berbahasa berarti bertanya tentang apa makna sebuah kata dan tanda yang dikatakan.

Peneliti Clifford Geertz misalnya pernah berkata, "dalam meneliti, kita tidak hanya mencatat, akan tetapi kita juga dicatat.” Dengan kata lain, meneliti secara kualitatif, tumpuan dan maknanya bersumber dari diri seorang peneliti. Peneliti berupaya untuk men-sintesis-kan hasil dekonstruksi masalah dengan hasil rekonstruksi dari konstruksi atribut. Sebab, bagi peneliti, meneliti adalah berpikir. Mendatangi lapangan kajian adalah melengkapi berpikir itu sendiri untuk merefleksikan realitas yang telah dipikirkan. Oleh karena, fenomena ber-atribut penampilan bukanlah suatu hal baru dalam pikiran setiap manusia yang berpikir, melainkan setiap manusia telah menyaksikannya di mana saja mereka berada dan mereka-pun telah memikirkannya. Namun, beratribut khas ibu-ibu anggota dewan dalam kurun waktu tertentu, merupakan refleksi peneliti untuk mengungkap ke-agungan jabatan khusus anggota dewan perwakilan rakyat dalam takaran pendekatan semiotika komunikasi.

Apabila ilmu komunikasi melihat atribut penampilan sebagai suatu pesan, semiotika melihatnya sebagai sebuah makna yang terbaring dan terintegrasi pada signifier dan signified. Signifier yang tampil sebagai actus selalu mengandaikan adanya animus signified yang meluap keluar dan bergerak dalam baringannya yang hanya dapat dilihat melalui "metabahasa". Hal ini sesuai dengan yang peneliti ungkapkan pada latarbelakang bahwa apabila ilmu-ilmu sosial lain meraba fenomena pada permukaan yang mengitari kehidupan manusia, maka semiotika bergerak masuk dan menyelam ke dalam tubuhnya fenomena untuk merefleksikan eksistensinya sebagai sebuah makna atau meaning. Dalam konteks paham semiotika struktural, eksistensi pesan selalu ada bersama di dalam dua aspek sekaligus yakni signifier sebagai bentuk luarnya, dan signified sebagai konsep dalamnya. Pengertian ini menjadi penting untuk memperkenalkan paham semiotika struktural bagi para mahasiswa guna melihat pesan komunikasi sebagai sebuah totalitas struktur yang mengandung binary opposition atau oposisi ke-dua-an. Manfaat dari analisis ke-dua-an ini, akan mempertajam daya analisis mahasiswa untuk semua masalah yang terkait dengan social scientific research.

Objek kajian pada tahap ini, ibarat daging mentah yang digoreng, diberi adonan bumbu lengkap, dan mematangkannya saat daya pikir bergerak secara continuun pada tempat yang terkukus, melalui sintesis kreatif dan produktif. Pada titik ini, logika ibarat api yang terus membakar wadah masak, dan pada tahap kulminasinya ia matang; matang dalam bentuk proposisi-proposisi yang tersaji. Pada tahap ini pula, peneliti melihat objek kajian atribut penampilan ibu-ibu anggota dewan, sebagai kajian khas dan menarik, oleh karena bersentuhan langsung dengan himpunan sekumpulan manusia 
femininum yang memiliki atribut, namun berstatus "lebih" tinggi dibandingkan dengan kaum feminin umumnya. Mereka beratribut dan berpenampilan sama seperti kaum perempuan lainnya. Namun, mereka juga adalah kelompok femininum pilihan untuk mewakili rakyat dalam menyambung aspirasiaspirasi dari sebuah bangsa dan Negara.

Terkait dengan penelitian kualitatif-induktif ini, semiotika komunikasi tampil dalam dua aspek sekaligus, yakni atribut berbusana tampil sebagai pesan yang ditransformasikan kepada pihak lain sebagai audiens yang melihatnya, dan menjadi sumber interpretasi sekaligus. Pada sisi lain, atribut penampilan dapat dilihat sebagai sebuah estetika dan tatanan seni terstruktur yang mapan, memiliki dua dimensi sekaligus, yang dalam konstruksi bahasa dapat menampilkan makna denotatif sesuai eksistensinya, namun pada saat yang sama, ia juga menampilkan sisi dalamnya sebagai konsep yang memiliki makna konotatif kontekstual. Dengan kata lain, lingkaran luar permukaan sebagai outer cycle bermakna denotatif, dan lingkaran dalam inner cycle sebagai konsep bermakna konotatif kontekstual.

Dalam konteks analisis di atas, peneliti mencoba meminjam bangunan logis Charles S. Peirce sesuai konteks penelitian ini berupa index dan simbol. Index adalah tanda yang mempunyai hubungan sebab-akibat dengan objek rujukannya; dan simbol adalah tanda yang mempunyai hubungan arbitrer dengan objeknya, yakni hubungan yang sewenang-wenang atau hubungan artifisial atau hubungan yang dibuat-buat. Dengan mengadopsi pengertian ini, peneliti ingin mengatakan bahwa atribut penampilan ibu-ibu anggota dewan dapat berakibat pada nilai axiologis-nya yakni apakah objek penelitian ini bermanfaat pada pengembangan nilai-nilai budaya yang dinamis. Apabila tak mendapatkan jawaban memadai dalam realitas, maka hasil penelitian dapat menjadi acuan untuk penelitian selanjutnya. Hasil penelitian ini sekaligus merupakan tanda yang memiliki hubungan arbitrer antara penanda dan petanda-nya. Makna yang diberikan terhadap objek penelitian induktif ini sebagai subjek penelitian, melahirkan sebuah makna baru yang signifikan, sekaligus melahirkan sebuah antinomi baru.

Charles Sanders Peirce menegaskan bahwa kita hanya dapat berpikir dengan sarana 'tanda'. Tanpa tanda manusia tidak dapat berkomunikasi, oleh karena tanda-tanda berkaitan erat dengan objekobjek yang menyerupai (icon), keberadaannya memiliki hubungan sebab-akibat (index) dengan tandatanda, karena ikatan konvensional (symbol) dengan tanda-tanda tersebut. Peirce menggunakan icon untuk relasi keserupaan dan kesamaannya. Index untuk tanda yang memiliki relasi kausatif dan simbol untuk asosiasi konvensional. Dengan demikian, analisis semiotik atribut penampilan memberi probabilitas untuk melihat fenomena atribut sebagai 'tanda' tidak hanya dari perspektif referensial dan informatif, melainkan lebih jauh mampu mengungkap aspek konseptual yang kontekstual sekaligus bersifat kultural.

\section{SIMPULAN}

Secara denotatif objek atau fenomena atribut penampilan ibu-ibu anggota dewan perwakilan rakyat Republik Indonesia, diserap dan ditangkap dengan indra sebagai hasil penelitian yang berwujud penanda (signifier). Namun, kedalaman objek fenomena atribut yang menyimpan makna sebagai noumena yang tersembunyi, yang perlu diinterpretasi berdasarkan jangkar-nya yakni realitas yang nampak pada penanda-nya adalah yang utama. Dari perspektif Barthes makna konotatif tingkat kedua terasa terinternalisasi. Namun, ketika meminjam dan menghadirkan perspektif Peirce, struktur ke-duaan atau binary opposition Barthes menjadi tak terlihat.

Index mencari hubungan sebab-akibat, dalam konteks penelitian ini menjadi nyata apabila dipertanyakan alasannya. Jika atribut penampilan adalah fenomena bermakna index sesuai konsep Peirce maka akibatnya akan melahirkan nilai axiologis yang akan selalu berdaur ulang dan dapat 
dilihat sebagai konstatasi dinamika budaya, dalam pengembangan epistemologis-nya. Sebaliknya, simbol mencari hubungan asosiatif konvensional, akan menemukan makna relevan apabila "kata" atribut dan batik direlasikan langsung pada "atribut dan batik" objek substansi-nya, yang memiliki konsep lingkaran dalam-nya (inner cycle), dan (bukan atribut dan batik tertentu). Harapan peneliti adalah mencari komodifikasi fenomena atribut penampilan yang bermuatan nilai epistemologis dalam pengembangan nilai-nilai budaya untuk masyarakat Indonesia pada umumnya. Kenyataan di lapangan menunjukkan ketidaksamaan harapan oleh karena keterbatasan-keterbatasan yang ada. Komodifikasi dalam konteks penelitian ini adalah suatu upaya untuk mengubah apapun menjadi komoditas demi sebuah makna baru menurut perspektif semiotika komunikasi.

\section{DAFTAR PUSTAKA}

Barthes, R. (1990). The Fashion System. Los Angeles: University of California.

De Saussure, F. (1990). Course in General Linguistics. Duckworth, London.

Eco, U. (2009). Teori Semiotika. Yogyakarta: Kreasi Wacana Offset.

Eliade, Mircea (1989). Le Mythe de l'Eternel Retour. Archétypes et répétitions. Paris: Gallimard.

López-Varela, A. A. (2011). Intertextuality and Intermediality as Cross-cultural Comunication Tools: A Critical Inquiry. Cultura.

Peirce, C. S. (1978). Écrits sur le signe. Rassemblés, traduits et commentés par G. Deledalle. Paris: Seuil.

Piliang, Y. A. (2010). Semiotika dan hipersemiotika. Bandung: MATAHARI.

Yunus, U. \& Tulasi, D. (2012). Batik Semiotics as a media of communication in Java. Cultura, 9(2), 143-150. 